\title{
Is it Sustainable to Cultivate a Monoculture of Durum Wheat with Prolonged No-Tillage Management?
}

Troccoli ${ }^{1 *}$, Russo $\mathbf{M}^{1}$ and Farina $\mathbf{R}^{\mathbf{2}}$

${ }^{1}$ Consiglio per la ricerca in agricoltura e l'analisi

dell'economia agraria, Centro di ricerca cerealicoltura e colture industriali, Foggia, Italy

${ }^{2}$ Consiglio per la ricerca in agricoltura e l'analisi dell'economia agraria, Centro di ricerca agricoltura e ambiente, Rome, Italy

*Corresponding author: Antonio Troccoli, Consiglio per la ricerca in agricoltura e l'analisi dell'economia agraria, Centro di ricerca cerealicoltura e colture industriali, Foggia, Italy

Received: December 01, 2021; Accepted: J anuary 03, 2022; Published: J anuary 10, 2022

\begin{abstract}
The prolonged effect of no-tillage (NT) and conventional tillage (CT) treatment on durum wheat (Triticum durum Desf.), continuously grown in Southern Italy, has been evaluated in experimental fields for sixteen years (1994/95-2009/10) to ascertain whether the yields and quality of the grain as well as some soil characteristics had changed. The average grain yield in CT $\left(2.70 \pm 0.96 \mathrm{tha}^{-1}\right)$ and NT $\left(2.63 \pm 0.74 \mathrm{t} \mathrm{ha}^{-1}\right)$ treatment was not significant. CT treatment showed higher values of plant height and grain weight $(74.2 \mathrm{~cm}$ and $43.2 \mathrm{~g})$ than NT $(71.0 \mathrm{~cm}$ and $41.8 \mathrm{~g})$. Regarding to the semolina quality, the values of the gluten index and the dough strength (W parameter) as well as the protein content and the yellow index were not significantly different for the NT and CT treatments. As for soil moisture, the NT treatment stored in the soil profile, and over time, about $13 \%$ more water than the CT one. In the upper soil layer of the NT treatment the SOC value $\left(16.0 \pm 2.2 \mathrm{~g} \mathrm{~kg}^{-1}\right)$ was $13.2 \%$ higher than CT one $\left(14.2 \pm 1.2 \mathrm{~g} \mathrm{~kg}^{-1}\right)$ while the CT treatment $\left(13.7 \pm 0.5 \mathrm{~g} \mathrm{~kg}^{-1}\right)$ showed in the lower soil layer a SOC value of $30.2 \%$ higher than the NT one $(9.6 \pm 1.9 \mathrm{~g}$ $\left.\mathrm{kg}^{-1}\right)$. Hence the prolonged no-tillage adoption in conditions of continuous durum wheat cultivation, even with slight losses in yield but not in the quality of grain or semolina, would seem sustainable.
\end{abstract}

Keywords: Durum wheat monoculture; No-tillage; Sustainability; Soil moisture content; Soil organic carbon

\section{Introduction}

Long-term experiments represent a via for testing the sustainability of different farming practices, for example yields trend over decades, also when the same practices can be considered unsustainable. Experiments at Rothamsted are a classic demonstration that "grain yields can be sustained (and even increased) for almost 150 years in monocultures of wheat and barley given organic or inorganic fertilizer annually" [1].

These results show that some practices considered agronomically unsustainable, as monoculture, however can be maintained, providing the farm the ability to produce the same crop perpetually, clearly under certain circumstances.

Similarly, an agricultural system addressed to obtain constant and durable yields without depleting soil fertility can be considered an eco-sustainable integrated system since it uses less non renewable resources and promotes the reduction of costs for both the production and environment [2]. The FAO in 90's launched the concept of "sustainable agriculture": "productive activity that aims to the conservation of soil, water, plant and animal genetic patrimony, technically adequate, economically valid, and socially acceptable".

Farmers generally consider the production level of the durum wheat to be an important parameter but in variable or unfavourable agro-climatic conditions they find the yield stability more interesting [3]. However, yield stability as well as the level of production of durum wheat can be strongly conditioned by several factors: agricultural practices (soil tillage, fertilization, irrigation, weed and pest control, residues management and others), soil properties (texture, OM, nutrients availability, microbial activity, $\mathrm{pH}$, moisture and others), type of crop (monoculture, rotation with oilseeds, legumes or cover crop) besides to climate conditions, especially high heat and low rain during grain ripening [4-9].

Among the agricultural sustainable practices, the no-tillage represents one of the three approaches included in the conservation agriculture concept [10] that can help in maintaining crop productivity, soil fertility and environmental sustainability. Regarding the effects of no-tillage on crop yields, studies carried out on this aspect report controversial results: some show that yields in reduced or no tillage systems are like those of conventional tillage [11], unlike others where yields decreased [9]. An overview of the effects of no tillage on crop yields was provided by Pittelkow et al. [12] who performed a metaanalysis on 678 studies and 6005 observations, including 50 crops and 63 countries. They find no-till yields matched conventional tillage yields for oilseed, cotton, and legume crop categories while, among cereals, the negative impacts of no-till were smallest for wheat $(-2.6 \%)$ and largest for rice (-7.5\%) and maize (-7.6\%). No-till performed best under rainfed conditions in dry climates, with yields often being equal to or higher than conventional tillage practices. Furthermore, yields in the first 1-2 years following no-till implementation declined for all crops except oilseeds and cotton, but matched conventional tillage yields after 3-10 years except for maize and wheat in humid climates. Finally, the overall yields in the no-till system were reduced by $12 \%$ without the addition of nitrogen fertilizer and by $4 \%$ with the addition of inorganic nitrogen. 
However, it is generally recognized that no-till is an agricultural practice that leads to significant benefits of both an environmental nature (reduction of wind and water erosion; increase in soil biological activity, nutrient cycle, soil water retention capacity, infiltration of water and efficiency in the use of water) and economic (greater profitability due to the decrease in energy consumption and labor) [13-15].

As important indicators of the soil quality, an interesting debate concerns the effect of no-tillage on the carbon and nitrogen content of the soil, especially if it is true that undisturbed agricultural soils can recover higher quantities of these elements than the conventional tillage system.

The regular use of moldboard plough for seedbed preparation or disking for weed control can result in a significant decline in soil of organic matter content [16,17]. Accordingly, the loss of soil organic C may be due to disruption of soil aggregates [18], stimulation of shortterm microbial activity by enhanced aeration [19], and decomposition into the soil of mix fresh. A further loss of $\mathrm{C}$ organic may derive from erosive phenomena due to action of wind or water (runoff) on soil tillage [20]. Adversely, under CA system the less disturbed soil results in a significant organic $\mathrm{C}$ accumulation [21] with consequent reduction of gas emissions, above all $\mathrm{CO}_{2}$, to the atmosphere [17]. In particular, it has been demonstrated that the $\mathrm{C}$ sequestration mainly occurs in the topsoil layers with little overall effect on $\mathrm{C}$ storage in deeper layers [13]. In fact, in a wheat-fall rotation system after 20 years of no-tillage application has been observed an increase of $6.7 \mathrm{t} \mathrm{C}$ $\mathrm{ha}^{-1}$ in the top $20 \mathrm{~cm}$ respect to conventional tillage [22]. Halvorson et al. [23] reported a decreasing pattern in SOC as NT $<\mathrm{MT}<\mathrm{CT}$ where the most SOC is retained under NT. Omara et al. [24] reported, under continuous monocropping practice, an average of $21 \%$ more SOC under NT than CT. In other studies, a significant SOC increase under NT was found to be $17 \%$ higher in long-term (39years) compared to short-term NT (9years) from the $0-15 \mathrm{~cm}$ soil layer, while no differences were observed between samples obtained from a $15-30 \mathrm{~cm}$ soil depth [25]. However, some controversies about the real capacity of no-tillage system to sequester a higher amount of soil C, especially when the whole soil profile is considered, are still unresolved [26] In fact, insignificant gain of soil C in the whole profile can take place depending on several factors like the amount of residues returned into soil, the variation in the agricultural practices implemented and the type of climate. As already seen, a lot of information regarding the variations of SOC and N storage under NT compared to CT is reported for the topsoil layer (up to $10 \mathrm{~cm}$ deep), whereas more information would be needed for the deeper soil layers [27]. Mazzoncini et al. [28] found that, under Mediterranean conditions and ten years after the start of the experiment, SOC and N concentrations in the $0-30 \mathrm{~cm}$ soil layer were already higher in the NT system than in CT. Furthermore, the highest increases in SOC and $\mathrm{N}$ concentrations occurred in the surface layer $(0-10 \mathrm{~cm})$ and no differences were observed in the deeper layers between tillage systems. After 28 years, the initial values of SOC and N content under NT increased by $22 \%$ in the soil depth of $30 \mathrm{~cm}$ while in CT conditions they decreased by $3 \%$ and $5 \%$, respectively. However, the mean gain of SOC and $\mathrm{N}$ contents under NT was mainly attributed to increases in the surface layer while in the soil layers of $10-20$ and $20-30 \mathrm{~cm}$ the accumulation of SOC over time was negligible even under NT.
Since crop yields improvement as well as the reduction of production costs are crucial factors for increasing the profitability production, particularly in the regions where the extensive agriculture is mostly diffuse, long-term studies are needed to properly evaluate the effectiveness of alternative soil managements as the conservative agriculture but also in order to support the decisions of stakeholders for specific public funding to farms that want to switch to CA, promoting the conversion of farm machinery adapted to the CA [29].

A field trial of tillage and no-tillage, which began in the 1994-95 cultivation season in Southern Italy (Foggia, Puglia) at the CREACI (Council for research and agricultural economics - Research centre for cereals and industrial crops) and currently in progress, was performed to assess whether a durum wheat crop sown continuously for sixteen years would lead to changes in yields and its components, grain quality and some soil properties.

\section{Materials and Methods}

\section{Description of experimental site}

The trial has been started in 1994/'95 growing season and it is still in progress at the experimental farm $\left(41^{\circ} 27^{\prime} 57^{\prime \prime} \mathrm{N}\right.$; $15^{\circ} 30^{\prime} 20^{\prime \prime} \mathrm{E} ; 80$ $m$ a.s.l.) of CREA-CI of Foggia (Apulia, Southern Italy), a typically Mediterranean environment. The soil has a clay-loam texture and is classified as Typic Calcixerept [30]. Some properties of the soil profile are reported in Table 1.

Table 2 shows a synthetic climatic description of the experimental site where the meteorological conditions of both the annual and the growing season of the pre-field test period (1955-1994) are compared with those of the field test (1995-2010). It can be noted that in the period 1995-2010 the climate was slightly rainier but with temperatures, especially the minimum, on average higher than the previous one. However, in both periods the most critical phenological phases of durum wheat (from earing to grain ripening) were characterized by a dry climate, according to the Sielianinov hydrothermal K factor [31]. In general, the climate type is meso-Mediterranean (sub-humid) lower and ombrotype dry upper, with the presence of a dry season between May and September and the possible return of cold during the spring (March-April) [32].

\section{Experiment description}

In 1994 an experimental area of $12,000 \mathrm{~m}^{2}$ was divided into two contiguous plots of $6,000 \mathrm{~m}^{2}$. One area was converted to conservative agriculture, with no-tillage management (NT) and direct soil seeding using suitable seeding machinery, while the other area was kept on conventional tillage (CT), carrying out moldboard ploughing to $30 \mathrm{~cm}$ depth followed by a disc-harrow and flexible harrow for the seedbed preparation. Ofanto (1994-2005) and Lesina (2005 onward) varieties of durum wheat (Triticum durum Desf.) were used. After harvesting in NT and CT plots, the wheat straw was removed from the field while the stubble was chopped and left on the surface in NT treatment or incorporated with tillage in CT plot.

For seedbed preparation, $36 \mathrm{~kg} \mathrm{~N}^{-1}$ plus $42 \mathrm{~kg} \mathrm{P}^{\mathrm{P}} \mathrm{ha}^{-1}$, as diammonium phosphate (18-46-00), were spread on the CT field and incorporated into the soil with secondary tillage, while in the field NT the same fertilizer was spread and left on the surface. Due to the high availability in the soil of exchangeable potassium, this element was not supplied to the crop. 
Table 1: Main physical and chemical characteristics of a soil profile (0-160 cm soil depth) carried out in 1996 in the experimental site of CREA-Cl of Foggia.

\begin{tabular}{|c|c|c|c|c|c|c|c|c|c|}
\hline Horizon & $\begin{array}{l}\text { Depth } \\
\text { (cm) }\end{array}$ & $\begin{array}{l}\text { Sand } \\
\left(g_{k g}^{-1}\right)\end{array}$ & $\begin{array}{c}\text { Silt } \\
\left(\mathrm{gkg}^{-1}\right)\end{array}$ & $\begin{array}{c}\text { Clay } \\
\left(g^{-1} g^{-1}\right)\end{array}$ & $\begin{array}{c}\text { Total Carbonate } \\
\left(\mathrm{gkg}^{-1}\right)\end{array}$ & $\begin{array}{c}\mathrm{pH} \\
\left(\mathrm{H}_{2} \mathrm{O} 1: 2.5\right)\end{array}$ & $\begin{array}{c}E C \\
\left.(\mathrm{dSm})^{-1}\right)\end{array}$ & $\begin{array}{c}\text { CEC } \\
\left(\mathrm{cmol}_{[+]} \mathbf{k g}^{-1}\right)\end{array}$ & $\begin{array}{c}\text { Organic C } \\
\left(\mathrm{gkg}^{-1}\right)\end{array}$ \\
\hline Ap & 40 & 225 & 411 & 364 & 146 & 8.6 & 0.29 & 42.44 & 11.11 \\
\hline Bwk & 65 & 436 & 376 & 188 & 154 & 8.3 & 0.19 & 40.96 & 11.3 \\
\hline C1k & 140 & 402 & 331 & 267 & 419 & 8.1 & 0.21 & 13.93 & 7.1 \\
\hline $\mathrm{C} 2 \mathrm{k}$ & 160 & 402 & 272 & 226 & 400 & 7.9 & 0.27 & 18.75 & 0.7 \\
\hline
\end{tabular}

EC: Electrical Conductivity; CEC: Cation Exchange Capacity.

Table 2: Climate characterization of the experimental site (CREA-Cl of Foggia).

\begin{tabular}{|c|c|c|c|}
\hline \multirow{2}{*}{ Reference period } & Pre-Field Test (PFT) & Field Test (FT) & FT vs. PFT \\
\hline & 1955-1994 & $1995-2010$ & (\%) \\
\hline \multicolumn{4}{|l|}{ Rain (mm) } \\
\hline Yearly & 525 & 550 & 4.8 \\
\hline Seasonal (Oct-Jun) & 407 & 447 & 9.8 \\
\hline \multicolumn{4}{|l|}{ Average Temperature $\left({ }^{\circ} \mathrm{C}\right)$} \\
\hline Yearly & 13.1 & 13.5 & 3.1 \\
\hline Seasonal (Oct-Jun) & 11.3 & 12 & 6.2 \\
\hline \multicolumn{4}{|l|}{ Maximum Temperature $\left({ }^{\circ} \mathrm{C}\right)$} \\
\hline Yearly & 21.5 & 22.4 & 4.2 \\
\hline Seasonal (Oct-Jun) & 18.2 & 19.3 & 6 \\
\hline \multicolumn{4}{|l|}{ Minimum Temperature $\left({ }^{\circ} \mathrm{C}\right)$} \\
\hline Yearly & 9.4 & 10.8 & 14.9 \\
\hline Seasonal (Oct-Jun) & 6.8 & 8.6 & 26.5 \\
\hline \multicolumn{4}{|l|}{ Hydrothermal Sielianinov K factor } \\
\hline Critical for durum wheat (Apr-Jun: heading-flowering- grain filling and maturation) & 0.92 & 0.92 & Dry climate \\
\hline
\end{tabular}

Based on the average percentage of germination, the weight of 100 seeds and the number of 350 viable seeds $\mathrm{m}^{-2}$, the quantity of coated seeds per hectare to be used in the CT and NT treatments was calculated. A 24-row pneumatic seeder and a 16-row GASPARDO "Directa" seeder were respectively used for the CT and NT treatment. Top dressing (64 $\mathrm{kg} \mathrm{N} \mathrm{ha}^{-1}$ as ammonium nitrate) was applied in both plots at 21-29 tillering stage, according to $\mathrm{BBCH}$ scale [33], followed by an application of specific herbicides for grasses and broadleaf weeds. In NT plots the weeds were controlled before sowing with glyphosate.

\section{Data collection}

From 1994-1995 growing season, durum wheat (Triticum durum Desf.) was continuously sown in NT and CT treatments. Therefore, three random harvest areas within of NT and CT plot were collected each year to determine grain yield ( $\mathrm{t} \mathrm{ha} \mathrm{a}^{-1}$ adjusted to $13 \%$ grain moisture). After a period of time necessary to reach the equilibrium phase of the NT system, from 1997-1998 growing season also other traits such as plant height $(\mathrm{PH}, \mathrm{cm}$, excluding awn), number of plants $\left(\mathrm{PN}, \mathrm{n} . \mathrm{m}^{-2}\right)$, harvest index (HI, obtained as the ratio between the weight total, $\mathrm{g} \mathrm{m}^{-2}$, of grain and above-ground biomass and expressed as a percentage), the 1000-kernel weight (TKW, g) and, using the INFRATEC equipment (FOSS, Italy), test weight (TW, $\mathrm{kg} \mathrm{hL}^{-1}$ ), protein (PC, \% d.m.b.) and gluten content (GC, \% d.m.b.) in the grain were measured in triplicate. From 2003 to 2008 also some traits of semolina, using the Chopin's alveograph, such as the strength (W, $\left.10^{-4} \mathrm{~J}\right)$ and the configuration ratio $(\mathrm{P} / \mathrm{L}$ index where $\mathrm{P}=$ tenacity and $\mathrm{L}=$ extension) of dough or the yellow index (YI), using the Minolta's colorimeter, were analyzed in duplicate on grain samples coming from CT and NT treatments.

During the 1998-1999 growing season, the trend of soil moisture content in the NT and CT treatment was analyzed with the gravimetric method from the heading to the stage of full maturity of durum wheat. Four duplicate soil samples were collected on April 23, May 6 and 20 and June 3 and 10, considering four depth levels for each measurement: $0-15,15-30,30-45$ and $45-60 \mathrm{~cm}$. The soil moisture content (SMC) was expressed as a percentage based on the weight of the dry soil.

In October 2008 and 2009, soil organic carbon (SOC, $\mathrm{g} \mathrm{kg}^{-1}$ ) was measured in CT and NT treatments, considering five depth levels: $0-10,10-20,20-30,30-40$ and $40-50 \mathrm{~cm}$. SOC was analyzed by means of LECO RC612 Carbon Analyzer.

\section{Statistical analysis}

All statistical analysis was carried out using STATISTICA (software for data analysis) v. 7.1 (StatSoft Italia s.r.l.). For all traits analyzed, a mixed ANOVA was used, considering the management factor as fixed and the year factor random. The comparison among means was performed using Least Significant Difference test at $\mathrm{P}=5 \%$.

\section{Results and Discussion}

\section{Grain yield}

The main brake on farmers' adoption of CA is the risk of lower yields when no-tillage management is used. 


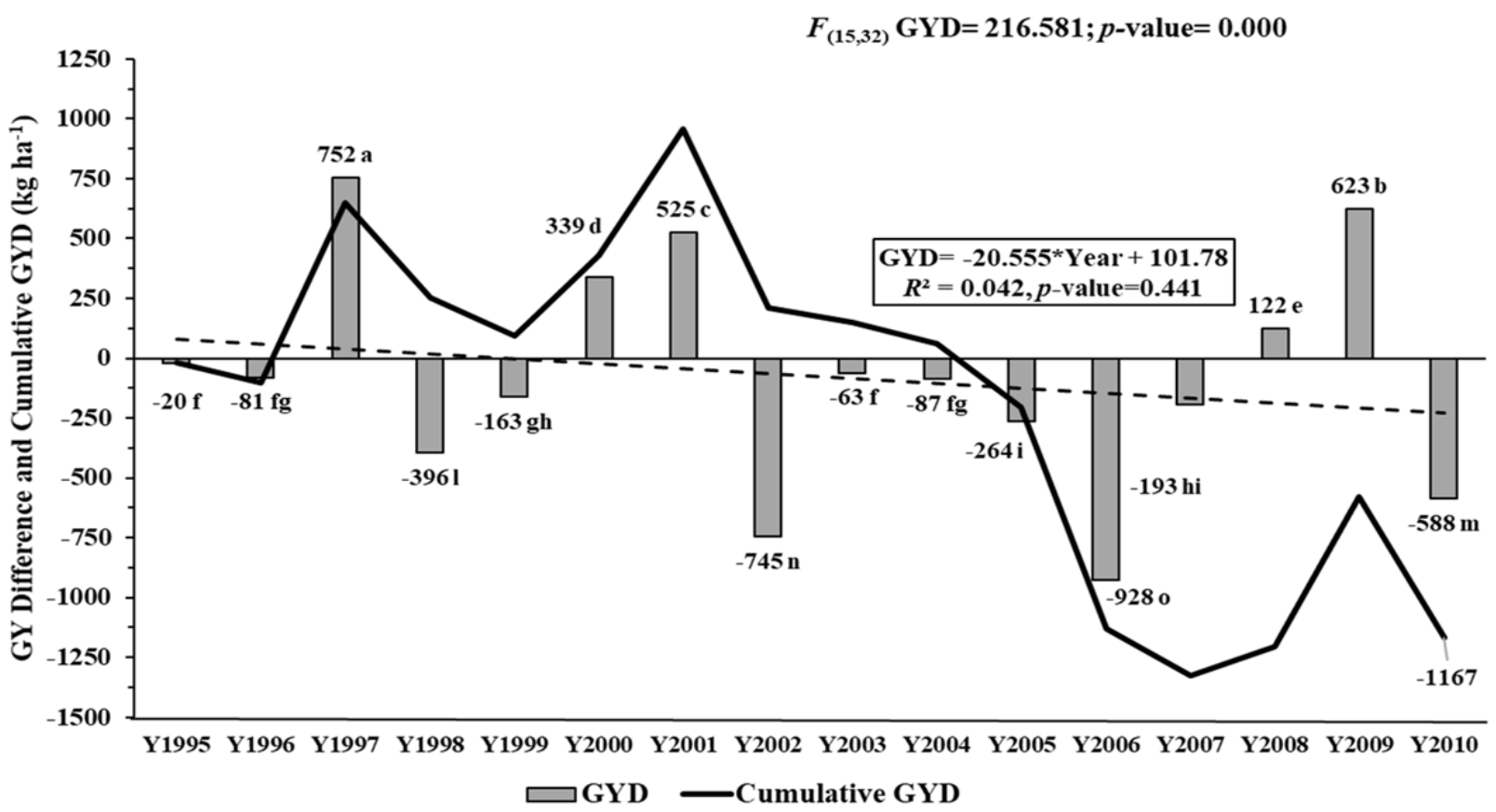

Figure 1: Annual and Cumulative trend in Grain Yield Difference (GYD) of No-Tillage (NT) vs. Conventional Tillage (CT). For each bar, values with different lowercase letters are significant at $P=5 \%$, according to the Least Significant Difference test.

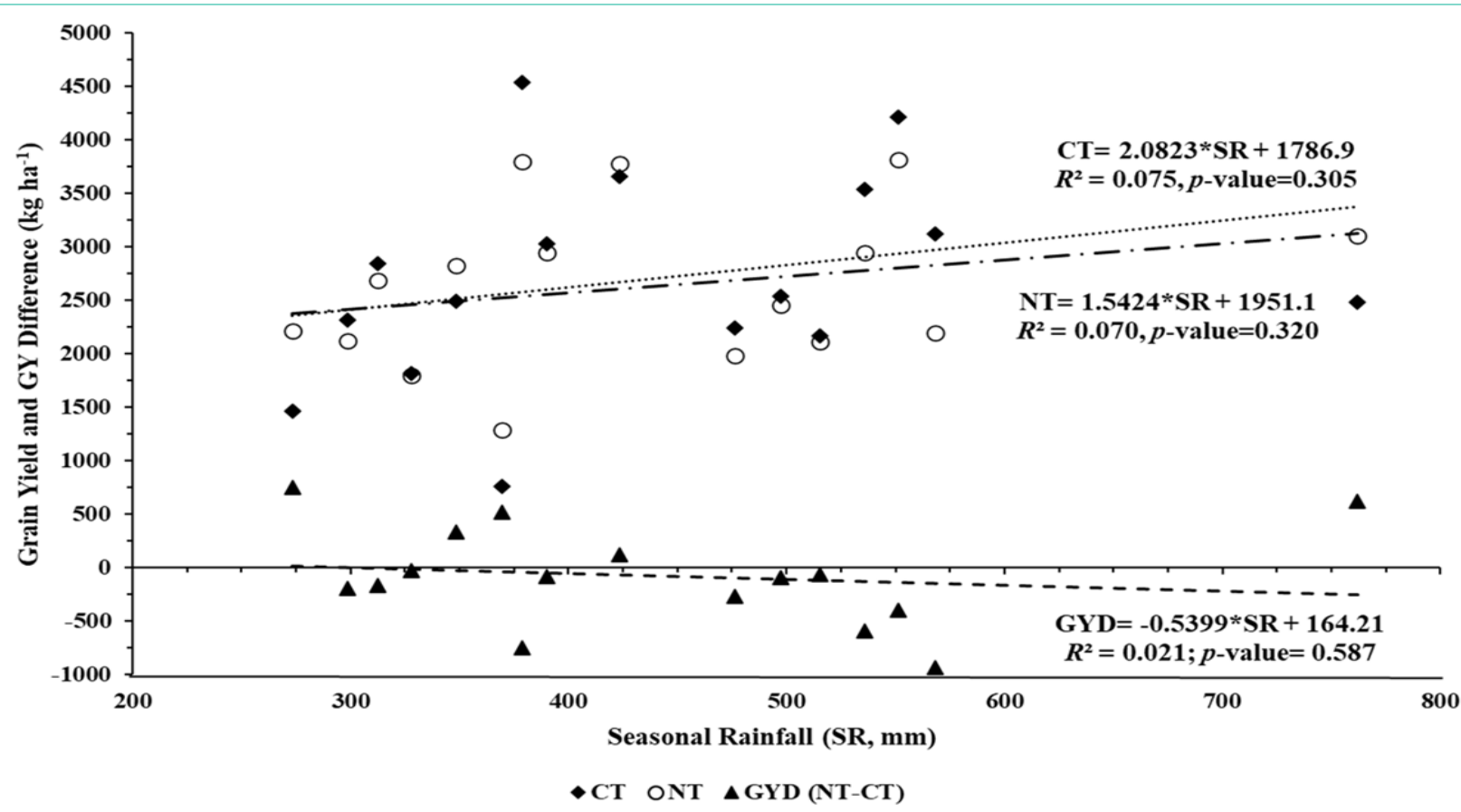

Figure 2: Linear regression performed between the grain yields (GY) of No-Tillage (NT), Conventional Tillage (CT) and difference (GYD) between NT and CT treatments and total Seasonal Rainfall $(\mathrm{mm})$ recorded from October to June of each year.

Bonfil et al. [34] found no differences in grain yields in Israel with both NT and CT in a normal year, while NT yields were higher than those of CT in drought years. A meta-analysis performed by Pittelkow et al. [7] showed that the average yields of no-tillage were approximately $5-10 \%$ lower than conventional tillage, but in dry climate conditions the yields of CA were higher than those of CT.
Ruisi et al. [35], after 20 years of soil tillage performed in southern Italy, Sicily, found a better yield of NT compared to CT only in the drier and less productive growing seasons. Van de Putte et al. [36] found a reduction in yields of 4.5-8.5\% under NT conditions, but no increase in NT yields in drier climatic conditions.

In our long-term tillage experiment, the results agree with 
Table 3: Mean values \pm standard deviation $(n=30 ; 1998,2000,2003-2010)$ of yield components and grain quality of durum wheat grown continuously in the No-Tillage (NT) and Conventional Tillage (CT) treatments.

\begin{tabular}{|c|c|c|c|c|c|c|c|}
\hline Treatment & $\begin{array}{l}\text { Plant Height } \\
\text { (cm) }\end{array}$ & $\begin{array}{l}\text { Spike number } \\
\left(\mathrm{nm}^{-2}\right)\end{array}$ & $\begin{array}{l}\text { Harvest index } \\
(\%)\end{array}$ & $\begin{array}{c}\text { 1000-kernels weight } \\
\text { (g) }\end{array}$ & $\begin{array}{l}\text { Test weight } \\
\left(\mathrm{kghL}^{-1}\right)\end{array}$ & $\begin{array}{c}\text { Protein content (\% } \\
\text { s.s.) }\end{array}$ & $\begin{array}{c}\text { Gluten content (\% } \\
\text { s.s.) }\end{array}$ \\
\hline $\mathrm{CT}$ & 74 & 286.5 & 32.6 & 43.2 & 77.7 & 13 & 9.6 \\
\hline $\pm s d$ & 5.7 & 57.4 & 6.8 & 3.7 & 1.7 & 1.3 & 1.7 \\
\hline NT & 71 & 276 & 33.8 & 41.8 & 77.8 & 13.2 & 9.8 \\
\hline $\pm s d$ & 8.7 & 45.9 & 6.7 & 2.6 & 1.6 & 1.2 & 1.1 \\
\hline Mean & 72.5 & 281.3 & 33.2 & 42.6 & 77.7 & 13.1 & 9.7 \\
\hline $\pm s d$ & 7.4 & 51.8 & 6.7 & 3.3 & 1.7 & 1.2 & 1.4 \\
\hline $\begin{array}{c}F_{(1,49)} \\
\text { Treatment }\end{array}$ & 1.159 & 1.099 & 3.306 & 5.406 & 0.006 & 1.184 & 1.033 \\
\hline$p$-value & 0.001 & 0.3 & 0.075 & 0.024 & 0.937 & 0.282 & 0.314 \\
\hline
\end{tabular}

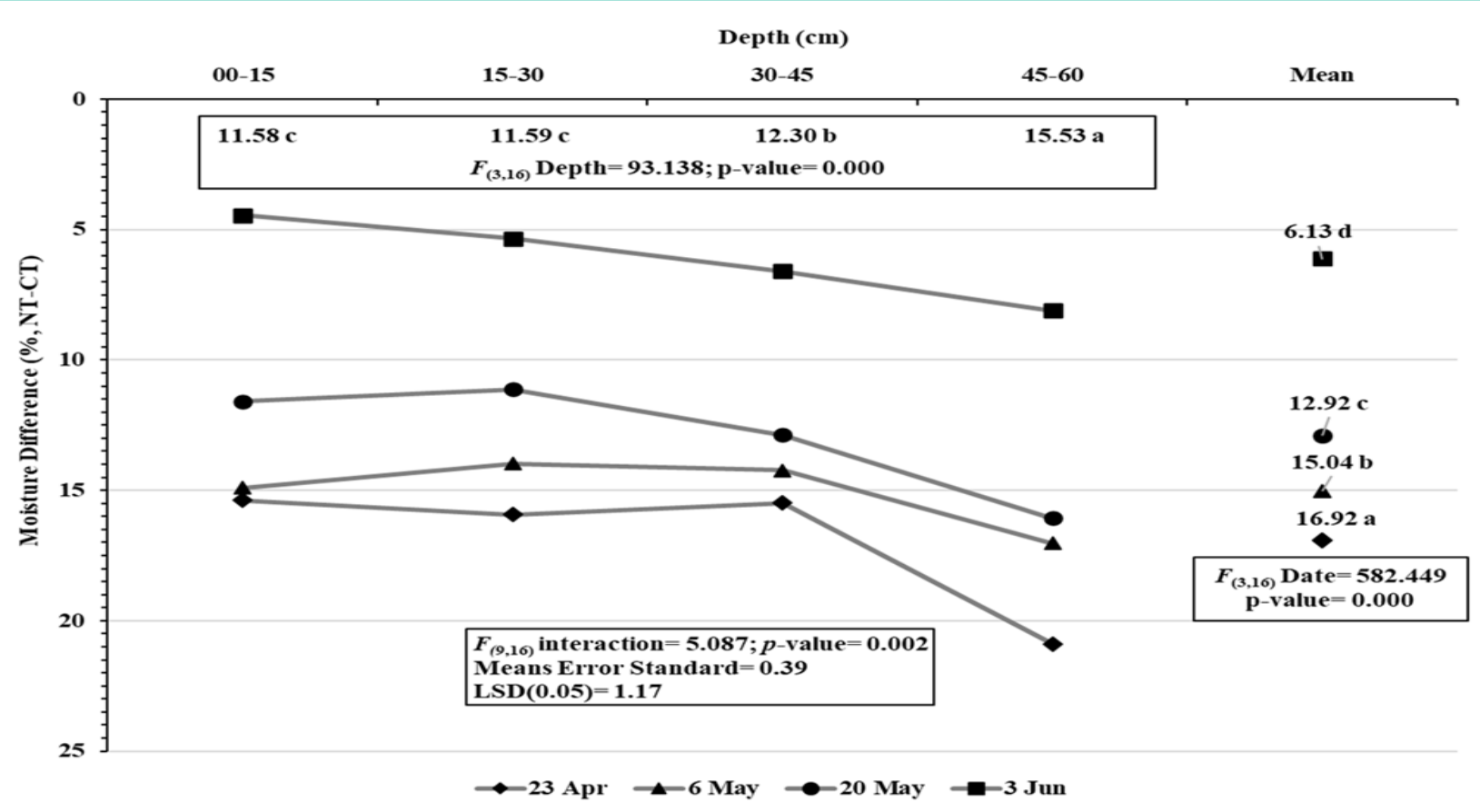

Figure 3: Mean values of the difference in soil moisture, expressed as percentage, between No-Tillage and Conventional Tillage recorded in 1999 at four depth levels $(0-15-30-45-60 \mathrm{~cm})$ and on four dates (23 April, 6 and 20 May, and 3 June) during growing season (from earing to maturity stage) of durum wheat. Different lowercase letters next to the means indicate a significant difference at $P=5 \%$, according to the Least Significant Different test.

previous reports. Grain yields for the two treatments were not significant $\left(F_{(1,15)}=0.382, p\right.$-value $\left.=0.182\right)$, being $2.70 \pm 0.96 \mathrm{t} \mathrm{ha}^{-1}$ the average grain yield of CT and $2.63 \pm 0.74 \mathrm{t} \mathrm{ha}^{-1}$ that of NT $(2.7 \%$ less). As expect, the yields variability during the 1955-2010 period resulted be highly significant (range of $1.02 \pm 0.29-4.17 \pm 0.42 \mathrm{t} \mathrm{ha}^{-1}$; $F_{(15,15)}=12.616, p$-value $\left.=0.000\right)$ as well as the interaction of treatment $\mathrm{x}$ year (range of $1.29 \pm 0.04-3.71 \pm 0.11 \mathrm{t} \mathrm{ha}^{-1}$ for NT and $0.76 \pm$ $0.02-4.54 \pm 0.14 \mathrm{t} \mathrm{ha}^{-1}$ for CT; $F_{(15,64)}=38.539, p$-value $=0.000$ ). Figure 1 shows the annual and cumulative trend of the difference in yield between NT and CT treatments. Although linear regression shows an insignificant negative slope of the difference in yields, the production of NT seems likely to decline over the years. In fact, the cumulative trend of the difference in yield (GYD) shows in 2004 the transition point of the curve where it is possible to note that in the first ten years (1995-2004) of the experimentation the NT system is generally more competitive than the CT system while in the following period CT yields, except in 2009, are consistently better than NT ones. In
2004 the cumulative yields remained positive of $60 \mathrm{~kg} \mathrm{ha}^{-1}$ for the NT system while in 2010 the cumulative loss of NT reached $1,167 \mathrm{~kg} \mathrm{ha}^{-1}$.

Weather conditions during the growing season can play a role in the grain yield response of durum wheat, particularly rainfall during grain filling. In Figure 2 the grain yield values of NT and CT as well as GYD were regressed on the total seasonal rainfall recorded from October to June of each year. Although the three linear regressions showed a low and insignificant value of the coefficient of determination $\left(R^{2}\right)$, the angular coefficients were positive for CT and NT treatment but negative for GYD, indicating that durum wheat performed best in NT treatment when during the growing season the total rainfall did not exceed $400 \mathrm{~mm}$.

Other studies demonstrated the relationship between yield and seasonal rainfall. In Bushland Texas, an environment like arid area of Syria, Army et al. [37] showed that seasonal rainfall accounted for about $65 \%$ of the variation in dryland wheat yield. In the arid areas 
Table 4: Mean values \pm standard deviation $(n=18 ; 2003-2008)$ of semolina quality of durum wheat grown continuously in the No-Tillage (NT) and Conventional Tillage (CT) treatments.

\begin{tabular}{|c|c|c|c|c|c|}
\hline \multirow{2}{*}{ Treatment } & \multirow{2}{*}{ Protein content (\% d.m.b.) } & \multirow{2}{*}{ Gluten index (\%) } & \multirow{2}{*}{ Yellow index } & \multicolumn{2}{|c|}{ Alveograph parameters } \\
\hline & & & & $\mathrm{W}\left(10^{-4} \mathrm{~J}\right)$ & P/L \\
\hline CT & 11 & 79.4 & 20.5 & 142.9 & 1.94 \\
\hline $\pm s d$ & 0.5 & 17.8 & 1.5 & 47.8 & 0.81 \\
\hline NT & 11.3 & 73.2 & 20.9 & 139.5 & 2.03 \\
\hline $\pm s d$ & 0.7 & 14.3 & 1.8 & 38 & 0.67 \\
\hline Mean & 11.2 & 76.3 & 20.7 & 141.2 & 1.99 \\
\hline $\pm s d$ & 0.6 & 16.2 & 1.6 & 42.6 & 0.74 \\
\hline$F_{(1,29)}$ Treatment & 2.489 & 3.047 & 1.354 & 0.821 & 2.852 \\
\hline$p$-value & 0.126 & 0.091 & 0.254 & 0.372 & 0.102 \\
\hline
\end{tabular}

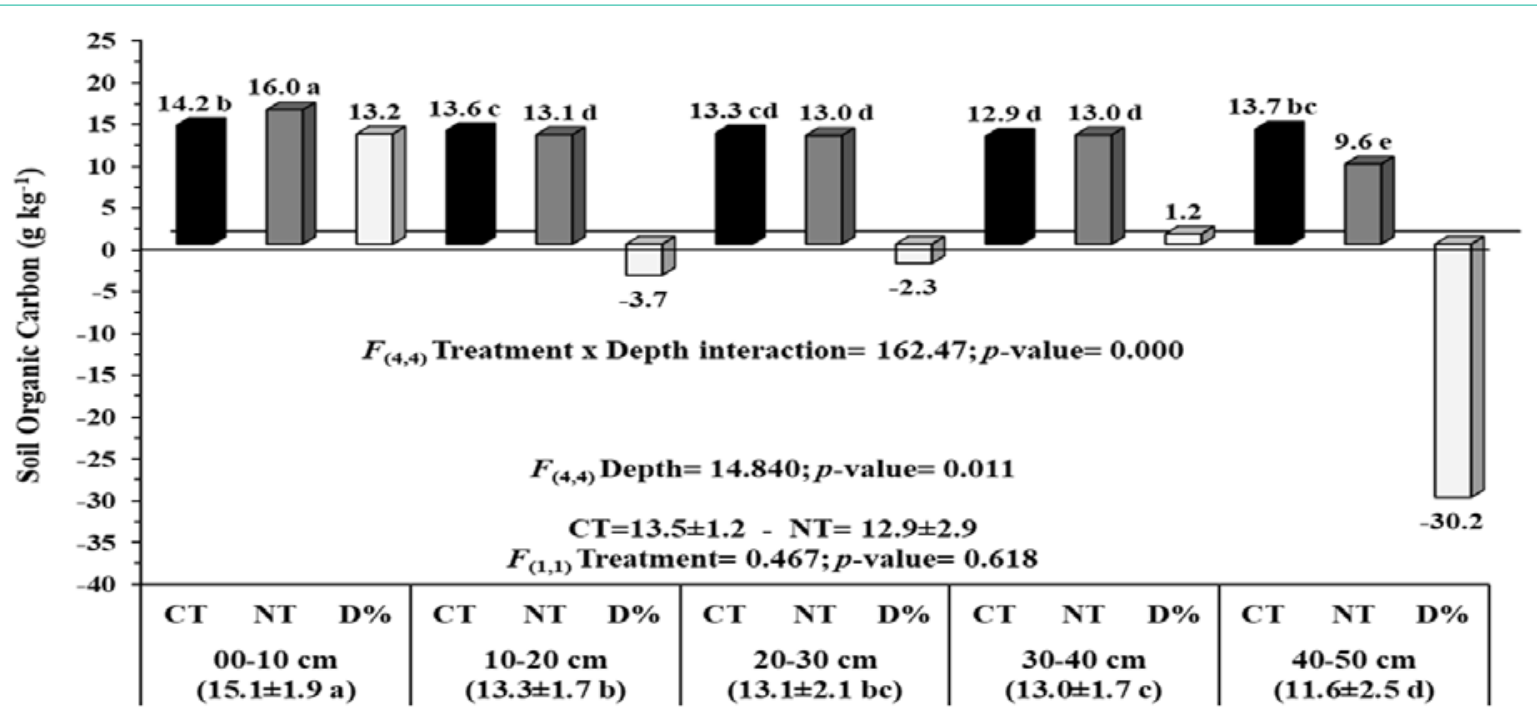

Figure 4: Soil organic carbon values for No-Tillage (NT, gray bars) and Conventional Tillage (CT, black bars) measured in October at five depths (10-20-30-40-50 $\mathrm{cm}$ ) during the 2008 and 2009 growing seasons. For NT and CT treatments and soil depth levels, the values are the mean ( $\mathrm{n}=20$ and $\mathrm{n}=8$, respectively) \pm standard deviation. Different lowercase letters next to the means indicate a significant difference at $P=5 \%$, according to the Least Significant Different test. For the treatment $x$ depth interaction, D\% (white bars) represents the difference, expressed as a percentage, between the NT and CT treatments.

of Syria, van Oosterom et al. [36] found that variation in seasonal rainfall (October-April) accounted for $50-60 \%$ of the variance in grain yield of the barley, with rainfall recorded in the months of December, January and April which represented the greatest contribution to the variation in yield. Austin et al. found that the wheat and barley crops of three farms in the Ebro valley in Spain were also highly dependent on seasonal rainfall, particularly rainfall recorded in the NovemberJanuary and March-May period of the growing season. In fact, in the driest farm (seasonal rainfall of $251 \mathrm{~mm}$ in Monegrillo, Zaragoza), yields increased by about 5.9 (wheat) and 9.4 (barley) $\mathrm{kg} \mathrm{ha}^{-1}$ per mm of extra rain during the entire growing season. In the other two farms (total 364 and $334 \mathrm{~mm}$ respectively in El Canós and Selvanera, Lleida province) the yields of barley increased by 4.3 and $9.0 \mathrm{~kg} \mathrm{ha}^{-1}$ per mm of extra rain, respectively.

In addition to the total rainfall recorded during the durum wheat growing season, it may also be important to assess whether monthly rainfall plays a role in yield response. A stepwise multiple regressions was performed considering the effect of monthly rainfall recorded from October to June of each year, also including total rainfall, on grain yield of NT and CT treatments. A large value of F was used in the regression model to insert or remove significant or insignificant variables. The regression analysis selected only monthly rain in May as the main variable able to significantly affect the grain yield of NT and CT treatments. Both treatments showed the same and significant value of the angular coefficient $\left(b=0.57 \pm 0.22 \mathrm{se} ; t_{(14)}=2.625\right.$ and $p$-value $=0.020)$ as well as a significant and similar value of the adjusted determination coefficient $\left(R_{\text {adj }}^{2}=0.282\right.$ and 0.280 for CT and NT treatments, respectively) of the regression model.

These results indicate that the total rainfall plays an important role when considers the tillage management of soil. In fact, the yields are more performing under conventional tillage system when total rainfall exceeds $400-500 \mathrm{~mm}$ while the no-tillage system seems to be more appropriate in drier climate conditions, but in both treatments the yields could be limited if, during the grain filling phase of the durum wheat, the total rainfall in May is insufficient to sustain the process.

\section{Yield components and grain quality}

As expected, all the characters analyzed were very significantly influenced by the year, while for the treatment factor a very significant 
difference was found only for the characteristics of the height of the plant and the weight of the grain, with the CT treatment showing higher values $(74.2 \mathrm{~cm}$ and $43.2 \mathrm{~g})$ than the NT one $(71.0 \mathrm{~cm}$ and 41.8 g). All the other characters, components of yield and quality of the grain, were not affected by the soil tillage technique, being the values very similar in both treatments (Table 3 ).

Although with the same resulted as our experiment, Woźniak et al. [38] observed that tillage influenced the number of plants per $\mathrm{m}^{2}$, resulting significantly lower in the NT treatment (381 plants $\mathrm{m}^{-2}$ ) than in the CT one (397 plants $\left.\mathrm{m}^{-2}\right)$. Coherent with our results, Bilalis et al. [39] found that the plant wheat height under NT (73.6 $\mathrm{cm})$ system were significantly lowest than CT $(79.9 \mathrm{~cm})$ as well as a higher 1000-kernels weight was found by Woźniak et al. [38] and Bilalis et al. [39] under CT (47.7 and $44.7 \mathrm{~g}$, respectively) compared to NT (45.7 and $41.5 \mathrm{~g}$, respectively) system. On the contrary, De Vita et al. [40] and Di Fonzo et al. [41] found that 1000-kernels weight was higher under NT. De Vita et al. [40], Gürsoy et al. [42] and Di Fonzo et al. [41] found that no-tillage significantly affected the test weight, while no effect on it was observed by Woźniak et al. [38] in $\mathrm{NT}$ and CT systems, in agreement with our results. Unlike our results, López-Bellido et al. [43], Woźniak et al. [38], Ruisi et al. [35] reported higher protein contents with the CT system while other studies have found, like us, that this parameter was not affected by tillage systems $[39,42,44,45]$. As in our experiment, when durum wheat was grown continuously for 18 years under NT and CT conditions, not even Ruisi et al. [35] found differences in the protein content of wheat.

\section{Semolina quality}

All the parameters, except protein content, showed a very significant seasonal variability while no effect of tillage factor was observed on all traits analyzed (Table 4). However, durum wheat grown under CT conditions appeared to have a better quality of the gluten index $(79.4 \%$ vs. $73.2 \%$ of NT) which resulted in better dough quality (142.9 W vs. $139.5 \mathrm{~W}$ of NT).

Tedone et al. [46] found a significant effect of different tillage methods (Conventional, Reduced and No-Tillage) on durum wheat quality in a 6yrs (2010-2015) field experiment at Policoro (Southern Italy). Unlike our result, they found the Chopin W parameter significantly best under CT or RT (275 or $270 \mathrm{~W}$ ) compared to NT system $(156 \mathrm{~W})$. This result was reasonably due to a significant reduction of grain protein content (14.3 and $14.2 \%$ respectively vs. $13.0 \%$ of NT) and an increase of non-vitreous kernels (3.4 and 5.1\% respectively vs. $20.7 \%$ of NT).

\section{Soil moisture content}

The Anova analysis showed for the date, depth and interaction factors a very significant effect on the difference of soil moisture content between NT and CT treatments (Figure 3). All relative moisture values underlined the importance of the NT treatment in retaining a greater amount of moisture in soil and in time. Along the soil profile, the water stock in NT treatment relatively increased from about $12 \%$, up to $30 \mathrm{~cm}$ depth, to about $16 \%$ at $60 \mathrm{~cm}$ depth compared to CT one; during growing season the water stock in NT was always higher than in CT but decreased from about $17 \%$ on 23 April to $6 \%$ on 3 June. Date $\mathrm{x}$ depth interaction showed differences in the moisture content trend. In the first two dates the moisture difference remained constant up to $45 \mathrm{~cm}$ depth and then rapidly degraded up to $60 \mathrm{~cm}$ depth; on the third date a drop in moisture was already evident at $30 \mathrm{~cm}$ depth, while on the last date the decrease in moisture was perfectly linear.

In agreement with our findings, De Vita et al. [40] found that, after measuring every 30 days the soil moisture content from sowing to maturity of durum wheat, the water content of the soil recorded during 2000/'01 and 2001/'02 growing seasons in south Italy was always higher under no-tillage (NT) compared to conventional tillage (CT) and in the NT treatment the soil water content was on average about 20\% higher than in CT. Ma et al. [47] found that soil water content and crop water use efficiency were improved under zero tillage with residue cover of oat. Similarly, Moreno et al. [48] also found that the no-tillage treatment stored greater amount of water in comparison to the conventional tillage and the difference was more obvious during the drier period of the year. On the contrary, Mohammad et al. [49] at different growth stages of wheat found similar moisture content in $0-30 \mathrm{~cm}$ upper soil in the tillage and notillage treatments. Uribe and Rouanet [50] tested the effect of three tillage systems (no-tillage and burning residues - NTBR, no-tillage without burning residues - NTWBR, and traditional tillage - TT) on moisture content in the soil profile. Between the growth phase of the end of tillering/beginning of internodes elongation and the earing they found that the mean value of the moisture index for NTWBR was 1.023 , significantly higher than 1.001 and 0.998 corresponding to NTBR and TT treatments; between the earing stage and the harvest the index for NTWBR was 0.963 , statistically higher than 0.941 and 0.938 corresponding to NTBR and TT treatments. This effect was mainly due to water content differences in the soil profile above 40 $\mathrm{cm}$. Considering the mean value of growth phases, the moisture index for NTWBR was 1.015, statistically higher than 0.996 and 0.990 of the NTBR and TT treatments.

\section{Soil organic carbon (SOC) content}

The soil profile opened in the 1996, next to the experimental field, showed a SOC value at $40 \mathrm{~cm}$ depth of $11.1 \mathrm{~g} \mathrm{~kg}^{-1}$ (Table 1). Hence, this value can be reasonably taken as a reference value of the initial SOC content of the experiment. In the years 2008-2009, in the profile up to $40 \mathrm{~cm}$ depth the mean SOC value for NT and CT treatment, statistically not significant, was of $12.9 \pm 2.9$ and $13.5 \pm 1.2 \mathrm{~g} \mathrm{~kg}^{-1}$, respectively (Figure 4). As regard to soil depth levels, the SOC values significantly degraded along the soil profile even though the most marked difference were in the upper $\left(15.1 \pm 1.9 \mathrm{~g} \mathrm{~kg}^{-1}\right)$ and lower $\left(11.6 \pm 2.5 \mathrm{~g} \mathrm{~kg}^{-1}\right)$ soil layers while from 20 to $40 \mathrm{~cm}$ depth the values were almost constant and just over $13.0 \mathrm{~g} \mathrm{~kg}^{-1}$.

The treatment $\mathrm{x}$ depth interaction was very significant, but the greater differences were found in the upper soil layer with NT treatment $\left(16.0 \pm 2.2 \mathrm{~g} \mathrm{~kg}^{-1}\right)$ having a SOC value of $13.2 \%$ higher than CT one $\left(14.2 \pm 1.2 \mathrm{~g} \mathrm{~kg}^{-1}\right)$ and in the lower soil layer where CT treatment $\left(13.7 \pm 0.5 \mathrm{~g} \mathrm{~kg}^{-1}\right)$ showed a SOC value of $30.2 \%$ higher than the NT one $\left(9.6 \pm 1.9 \mathrm{~g} \mathrm{~kg}^{-1}\right)$. In the intermediate soil layers (10$40 \mathrm{~cm}$ ) the differences between the NT and CT treatments were not relevant, being $-3.7 \%,-2.3 \%$ and $1.2 \%$ the difference found at the depth of 10-20 cm (CT > NT), 20-30 cm (CT > NT), and 30-40 cm $(\mathrm{NT}>\mathrm{CT})$, respectively.

In July 2009, after harvesting, an individual soil sample was collected at each depth level in the NT and CT treatment to check if 
the SOC content at the end of the durum wheat growing season (data not shown) had changed from at the start of the season (October 2008). In July 2009 , the mean level of SOC in NT $\left(12.1 \mathrm{~g} \mathrm{~kg}^{-1}\right)$ was slightly lower than that in CT $\left(12.7 \mathrm{~g} \mathrm{~kg}^{-1}\right)$ but compared to October 2008 both treatments had lower average SOC values (11.0 and 12.5 $\mathrm{g} \mathrm{kg}^{-1}$, respectively). As expected, the greater changes than October 2008 were found in the upper soil layer of both treatment but mostly in NT $\left(-18.4 \%, 11.6 \mathrm{~g} \mathrm{~kg}^{-1}\right)$ compared to that in CT $(-6.0 \%, 12.4 \mathrm{~g} \mathrm{~kg}$ $\left.{ }^{1}\right)$; in the subsequent soil layers, the SOC content was maintained at higher levels than in October 2008 and more consistently in the NT treatment $(16.9,20.5,17.2$ and $25.0 \%$, respectively) than in CT (1.7, 6.6, 9.5 and $-3.1 \%$, respectively). The greater loss of SOC found in NT treatment could result from more intense biological activity in the surface soil due to the high level of SOC in this layer. The work of Fornasier et al. [51] supports this statement since in 2011, after analyzing several soil samples from this experiment, they found a higher SOC content (49\%) as well as a very high $\beta$-glucosidase activity $(+400 \%)$ in the first $5 \mathrm{~cm}$ of soil of the NT treatment compared to the next layer of soil of $5-30 \mathrm{~cm}$. In fact, the $\beta$-glucosidase enzyme is widely distributed in nature and is related to the carbon cycle, acting in the cleavage of cellobiose into glucose molecules. Because of its sensitivity, this enzyme is considered a soil quality indicator and is directly related to the quantity and quality of soil organic matter [52].

In semiarid conditions, conservation agriculture has been recognized as an adequate system to increase soil organic carbon [23]. West and Post [53] have discovered that, by analyzing a large set of global data, the soil $\mathrm{C}$ sequestration increased with the adoption of no-tillage practices (NT), but with peaks after 5-10 years from the conversion to no-till. Previously, Franzluebbers and Arshad [54] had observed little to no detectable increase in SOC levels in the first 2-5 years of transition to conservation tillage, but a large increase after 5-10 years. Al-Kaisi et al. [55] found that NT resulted in significant increases in SOC of $14.7 \%$ compared with CT treatment after 3 years. The increases in SOC in NT treatment were not attributed to the vertical stratification of organic $\mathrm{C}$ in the soil profile or annual $\mathrm{C}$ inputs from crop residue, but most likely due to the decrease in soil organic matter mineralization in wet and cold soil conditions. They concluded that NT was superior to CT in increasing SOC in the top $15 \mathrm{~cm}$ in the short-term. In a study of 19-yrs carried out on a Sicily Vertisoil, Barbera et al. [56] found no significant difference in SOC levels by comparing a long-term NT system $\left(20.4 \mathrm{~g} \mathrm{~kg}^{-1}, \mathrm{n}=8\right)$ with a long-term moldboard ploughing system (19.7 $\left.\mathrm{g} \mathrm{kg}^{-1}, \mathrm{n}=8\right)$. They concluded that the high clay content in the soils protected SOM from decay, although CT was used; consequently, the conversion to NT can result in only a small effect on SOM.

\section{Conclusions}

Data coming from long-term studies are surely an important way to augment the knowledge in agricultural sector where often the "time" represents the key factor providing more certainty and safety toward the spatial-temporal variability that characterizes in general the agriculture.

The experimental results presented here offer encouraging justifications for promoting conservation agriculture, even in the most simplified form of no-tillage. In fact, the cultivation of durum wheat is advantageous in Mediterranean conditions when no tillage is used, although acceptable limitations may occur on the yield but not on the quality of the grain or semolina. The increase in the organic carbon content in the soil is also a very interesting aspect to consider when the no-tillage technique is adopted as a brake to counteract the loss of carbon due to tillage.

However, the adoption of no-tillage is only one of the fundamental principles on which the broader concept of Conservation Agriculture is based. In fact, two other key points complete the CA: the permanent soil cover with crop residues, crops or cover crops and the rotation of crops grown in sequence or in association are the other two indispensable factors to consider a farm adopting the principles of the CA.

Starting from the 2009/2010 growing season, the experimental field was transformed into full adoption of CA, including residue management and durum wheat-legume (Vicia faba var. minor Beck), the latter used as cover crop.

\section{Declaration}

Acknowledgements: For the characterization and analysis of the soil profile, we are thankful to Prof. Elio Coppola of the II University of Naples and his collaborators of the Pedology and Pedotechnics Working Group.

For the technical assistance in the field and part of the laboratory analyses, we thank the CREA-CI staff (Antonio Gallo, Aniello Padalino, Vito de Gregorio, Antonio Bruno, Angelo Olivieri, Giulio Carrabs and Pina Ferragonio).

Author contributions: AT managed the statistical analysis and visualization, literature review, and drafting and editing. MR and RF contributed to the laboratory analysis. All authors contribute to the article and approve the submitted version.

Funding details: Part of this work was supported by the Mi.P.A.F. Project Si.Cer.Me. "Sistema Integrato per lo sviluppo della Cerealicoltura Meridionale" (Ministerial Decree n. 353 of July 16, 2003).

Data availability statement: The original contributions presented in this study are included in the article, further inquiries can be directed to the corresponding author.

\section{References}

1. Jenkinsin DS. The Rothamsted long-term experiments, Are they still of use? Agron. J. 1991; 83: 2-10.

2. Masini S, Scaffidi C. Sementi e diritti. Grammatiche di libertà, ed. Slow Food, Bra (CN). 2008.

3. Macholdt, J, Honermeier B. Yield stability in winter wheat production: a survey on german farmers' and advisors' views. Agronomy. 2017; 7: 45.

4. Büchi L, Wendling M, Amossé C, Necpalova M, Charles R. Importance of cover crops in alleviating negative effects of reduced soil tillage and promoting soil fertility in a winter wheat cropping system. Agric. Ecosyst. Environ. 2018; 256: 92-104.

5. Blanchet G, Gavazov K, Bragazza L, Sinaj S. Responses of soil properties and crop yields to different inorganic and organic amendments in a Swiss conventional farming system. Agric. Ecosyst. Environ. 2016; 230: 116-126.

6. Song K, Yang J, Xue Y, Lv W, Zheng X, Pan J. Influence of tillage practices and straw incorporation on soil aggregates, organic carbon, and crop yields in a rice-wheat rotation system. Sci. Rep. 2016; 6. 
7. Pittelkow C, Liang X, Linquist BA, van Groenigen KJ, Lee J, Lundy ME, et al Productivity limits and potentials of the principles of conservation agriculture. Nature. 2015a; 517: 365-368.

8. Holzkämper A, Fossati D, Hiltbrunner J, Fuhrer J. Spatial and temporal trends in agro-climatic limitations to production potentials for grain maize and winter wheat in Switzerland. Reg. Environ. Chang. 2014; 15: 109-122.

9. Alvarez R, Steinbach HS. A review of the effects of tillage systems on some soil physical properties, water content, nitrate availability and crops yield in the Argentine Pampas. Soil Tillage Res. 2009.

10. FAO. Save and Grow: A Policymaker's Guide to the Sustainable Intensification of Smallholder Crop Production Food and Agriculture Organization of the United Nations (FAO), Rome. 2011.

11. Büchi L, Wendling M, Amossé $C$, Jeangros B, Sinaj S, Charles R. Long and short term changes in crop yield and soil properties induced by the reduction of soil tillage in a long term experiment in Switzerland. Soil Tillage Res. 2017; 174: $120-129$.

12. Pittelkow CM, Linquist BA, Lundy ME, Liang X, van Groenigen KJ, Lee J, et al. When does no-till yield more? A global meta-analysis. Field Crop. Res. 2015b; 183: 156-168.

13. Six J, Feller C, Denef K, Ogle SM, Sa JCM, Albrecht A. Soil organic matter biota and aggregation in temperate and tropical soils - effects of no-tillage. Agronomie. 2002; 22: 755-775.

14. Hobbs PR, Sayre K, Gupta R. The role of conservation agriculture in sustainable agriculture. Philos. Trans. R. Soc. B. 2008; 363: 543-555.

15. Verhulst V, Govaerts B, Verachtert E, Castellanos-Navarrete A, Mezzalama $M$, Wall $P$, et al. Conservation agriculture, improving soil quality for sustainable production systems? R. Lal, B.A. Stewart (Eds.), Advances in Soil Science: Food Security and Soil Quality, CRC Press, Boca Raton, FL, USA. 2010 137-208.

16. Lal R. Soil carbon dynamic in cropland and rangeland. Env. Poll. 2002; 116 : 353-362.

17. Paustian K, Six J, Elliott ET, Hunt HW. Management options for reducing $\mathrm{CO}_{2}$ emissions from agricultural soils. Biogeochemistry. 2000; 48: 147-163.

18. Soares JLN, Espindola CR, Pereira WLM. Physical properties of soils under intensive agricultural management. Scientia Agr. 2005; 62: 165-172.

19. Kladivko E. Tillage systems and soil ecology. Soil Till. Res. 2001; 61: 61-76.

20. Lal R. Enhancing crop yields in the developing countries through restoration of the soil organic carbon pool in agricultural lands. Land Degr. Dev. 2006; 17: $197-209$

21. Schuman GE, Janzen HH, Herrick JE. Soil carbon dynamics and potentia carbon sequestration by rangelands. Env. Poll. 2002; 116: 391-396.

22. Cambardella CA, Elliott ET. Particulate soil organic matter changes across a grassland cultivation sequence. Soil Sci. Soc. Am. J. 1992; 56: 777-783.

23. Halvorson AD, Wienhold BJ, Black AL. Tillage, nitrogen, and cropping system effects on soil carbon sequestration. Soil Sci. Soc. Am. J. 2002; 66: 906-912.

24. Omara P, Aula L, Eickhoff EM, Dhillon JS, Lynch T, Wehmeyer GB, et al. Influence of No-Tillage on Soil Organic Carbon, Total Soil Nitrogen, and Winter Wheat (Triticum aestivum L.) Grain Yield. Int. J. Agron. 2019; Article ID 9632969

25. Lafond GP, Walley F, May WE, Holzapfel CB. Long term impact of no-till on soil properties and crop productivity on the Canadian prairies. Soil Till. Res. 2011; 117: 110-123.

26. Smith P, Powlson DS, Glendining MJ, Smith JU. Preliminary estimates of the potential for carbon mitigation in European soils through no-till farming Global Change Biol. 1998; 4: 679-685.

27. Luo Z, Wang E, Sun OJ. Can no-tillage stimulate carbon sequestration in agricultural soils? A meta-analysis of paired experiments. Agric. Ecosyst. Environ. 2010; 139: 224-231.

28. Mazzoncini M, Antichi D, Di Bene C, Risaliti R, Petri M, Bonari E. Soil carbon and nitrogen changes after 28 years of no-tillage management under Mediterranean conditions. Eur. J. Agron. 2016; 77: 156-165.

29. Troccoli A, Maddaluno C, Mucci M, Russo M, Rinaldi M. Is it appropriate to support the farmers for adopting Conservation Agriculture? Economic and environmental impact assessment. Ital. J. Agr. 2015; 10: 661.

30. Soil Survey Staff. Keys to Soil Taxonomy. $12^{\text {th }}$ ed. USDA-Natural Resources Conservation Service. Washington D.C. USA. 2014.

31. Molga M. Basics of agricultural climatology. PWRiL Press, Warsaw, Poland. 1986.

32. Troccoli A, Colecchia SA, Cattivelli L, Gallo A. Caratterizzazione agroclimatica del capoluogo dauno - Analisi della serie storica delle temperature e delle precipitazioni rilevate a Foggia dal 1955 al 2006 (Agroclimatic characterization of the province of Foggia [Apulia region, Italy] - The time series analysis of temperatures and rains recorded in Foggia from 1955 to 2006). Tipografia Digital Print di Cannone s.a.s. (Orta Nova - FG). 2007

33. Meier U, Bleiholder $\mathrm{H}$, Buhr L, Feller $\mathrm{C}$, Hacks $\mathrm{H}$, Hess $\mathrm{M}$, et al. The BBCH system to coding the phenological growth stages of plants-history and publications. J. Cultiv. Plant. 2009; 2: 41-52.

34. Bonfil DJ, Mufradi I, Klitman S, Asido S. Wheat grain yield and soil profile water distribution in a no-till arid environment. Agron. J. 1999; 91: 368-373.

35. Ruisi P, Giambalvo D, Saia S, Di Miceli G, Frenda AS, Plaia A, et al Conservation tillage in a semiarid Mediterranean environment, results of 20 years of research. Ital. J. Agron. 2014; 9: 560.

36. van Oosterom EJ, Ceccarelli S, Peacock JM. Yield response of barley to rainfall and temperature in Mediterranean environments. J. Agric. Sci. 1993; 121: 307-313.

37. Army TJ, Bond JJ, Van Doren CE. Precipitation-yield relationships in dryland wheat production on medium to fine textured soils of the southern high plains. Agron. J. 1959; 51: 721-724.

38. Woźniak A, Makarski B, Stępniowska A. Effect of tillage system and previous crop on grain yield, grain quality and weed infestation of durum wheat. Romanian Agric. Res. 2014; 31: 129-137.

39. Bilalis D, Karkanis A, Patsiali S, Agriogianni M, Konstantas A, Triantafyllidis V. Performance of wheat varieties (Triticum aestivum L.) under conservation tillage practices in organic agriculture. Not. Bot. Horti. Agrobo. 2011; 39: 2833.

40. De Vita P, Di Paolo E, Fecondo G, Di Fonzo N, Pisante M. No-tillage and conventional tillage effects on durum wheat yield, grain quality and soil moisture content in southern Italy. Soil Till. Res. 2007; 92: 69-78.

41. Di Fonzo N, De Vita P, Gallo A, Fares C, Padalino O, Troccoli A. Crop Management Efficiency as a Tool to Improve Durum Wheat Quality in Mediterranean Areas, in: INRA Les Coloques no 99 (ed.), Durum Wheat, Semolina and Pasta Quality, Montpellier (France), Paris, France. 2001.

42. Gürsoy S, Sessiz A, Malhi SS. Short-term effects of tillage and residue management following cotton on grain yield and quality of wheat. Field Crops Res. 2010; 119: 260-268.

43. López-Bellido L, Fuentes M, Castillo JE, López-Garrido FJ. Effects of tillage, crop rotation and nitrogen fertilization on wheat-grain quality grown under rainfed Mediterranean conditions. Field Crops Res. 1988; 57: 265-276.

44. Rieger S, Richner W, Streit B, Frossard E, Liedgens M. Growth, yield, and yield components of winter wheat and the effects of tillage intensity, preceding crops, and N fertilisation. Eur. J. Agron. 2008; 28: 405-411.

45. Carr PM, Horsley RD, Poland WW. Tillage and seeding rate effects on wheat cultivars: I. Grain production. Crop Sci. 2003; 43: 202-209.

46. Tedone L, Alhajj Ali S, Verdini L, De Mastro G. Evaluation of agronomic strategies on crop production quality and environmental parameters of rainfed durum wheat in Southern Italy, in: Acquistucci R, Blandino M, Carcea M, D'Egidio MG, lametti S, Marconi E, et al. (Eds.), $10^{\text {th }}$ ICC/AISTEC Conference "Grains for feeding the world", Milan, Italy, 1-3 July 2015, CREA-AN, Rome. 2015: 150-155.

47. Ma Y, Qin H, Yin C-M, Gao W, Zhang H, Sui P, et al. Dynamics of soil water 
content under different tillage systems in agro-pastural eco-zone. Front Agric. China. 2008; 2: 208-215.

48. Moreno F, Pelegrin F, Fernandez JE, Murillo JM. Soil physical properties water depletion and crop development under traditional and conservation tillage in southern Spain. Soil Till. Res. 1997; 41: 25-42.

49. Mohammad W, Mahmood Shah S, Shehzadi S, Azam Shah S, Nawaz H Wheat and oat yields and water use efficiency as influenced by tillage under rainfed condition. Soil Environ. 2006; 25: 48-54.

50. Uribe HC, Rouanet JLM. Effect of three tillage systems on moisture content in the soil profile. Agric. Téc. 2002; 62: 555-564.

51. Fornasier F, Russo M, Troccoli A, Farina R. No tillage increased soi organic carbon and biological activity in a Mediterranean vertisol in Apulia Italy. Abstract of the $4^{\text {th }}$ International Congress of the ECSSS-European Confederation of Soil Science Societies - Session S07.07 Long-term effects of agronomic practices on soil organic matter and crop productivity. Bari, Italy. 2012: 1803.
52. de Almeida RF, Naves ER, da Mota RP. Soil quality: enzymatic activity of soi $\beta$-glucosidase. Glob. J. Agric. Res. Rev. 2015; 3: 146-150.

53. West TO, Post WM. Soil organic carbon sequestration rates by tillage and crop rotation, a global data analysis. Soil Sci. Soc. Am. J. 2002; 66: 19301946.

54. Franzluebbers AJ, Arshad MA. Soil organic matter pools during early adoption of conservation tillage in northwestern Canada. Soil Sci. Soc. Am. J. 1996; 60: 1422-1427.

55. Al-Kaisi MM, Yin X, Licht MA. Soil carbon and nitrogen changes as affected by tillage system and crop biomass in a corn-soybean rotation. App. Soil Ecol. 2005; 30: 174-191.

56. Barbera V, Poma I, Gristina L, Novara A, Egli M. Long-term cropping systems and tillage management effects on soil organic carbon stock and steady state level of $C$ sequestration rates in a semiarid environment. Land Degradation and Development. Published online in Wiley Online Library. 2010. 